\title{
TEXTURAL AND GEOCHEMICAL FEATURES OF FRESHWATER MICROBIALITES FROM LAGUNA BACALAR, QUINTANA ROO, MEXICO
}

\author{
SET I. CASTRO-CONTRERAS, ${ }^{1}$ MURRAY K. GINGRAS, ${ }^{1}$ ERNESTO PECOITS, ${ }^{1}$ NATALIE R. AUBET,,${ }^{1}$ DANIEL PETRASH, \\ SAULO M. CASTRO-CONTRERAS, ${ }^{1}$ GREGORY DICK, ${ }^{2}$ NOAH PLANAVSKY, ${ }^{3}$ AND KURT O. KONHAUSER ${ }^{1}$ \\ ${ }^{1}$ University of Alberta, Department of Earth and Atmospheric Science, 1-26 Earth Science Building, Edmonton, Alberta T6G 2E3, Canada \\ ${ }^{2}$ University of Michigan, Department of Earth and Environmental Science and Ecology and Evolutionary Biology, Ann Arbor, Michigan 48109, U.S.A. \\ ${ }^{3}$ California Institute of Technology, Division of Geological and Planetary Sciences, Pasadena, California 91125, U.S.A. \\ e-mail: sicastro@ualberta.ca
}

\begin{abstract}
Microbialites provide some of the oldest direct evidence of life on Earth. They reached their peak during the Proterozoic and declined afterward. Their decline has been attributed to grazing and/or burrowing by metazoans, to changes in ocean chemistry, or to competition with other calcifying organisms.

The freshwater microbialites at Laguna Bacalar (Mexico) provide an opportunity to better understand microbialite growth in terms of interaction between grazing organisms versus calcium carbonate precipitation. The Laguna Bacalar microbialites are described in terms of their distinct mesostructures. Stromatolites display internal lamination, attributed to the precipitation of calcite and the upward migration of cyanobacteria during periods of low sedimentation. Thrombolitic stromatolites show internal lamination in addition to internal clotting. The clotting is seen as a result of binding and/or trapping of micritic peloids by cyanobacteria and attributed to periods of high sedimentation. The carbonates in both microbialites had similar $\mathrm{C}$ - and $\mathrm{O}$ stable-isotopic signatures, both enriched in ${ }^{13} \mathrm{C}$ relative to bivalves, suggesting photosynthetic $\mathrm{CO}_{2}$ uptake was the trigger for carbonate precipitation. This implies that the rate of microbialite growth is largely a function of ambient carbonate saturation state, while the texture is especially dependent on accretion rates and sediment deposition on their surface. Importantly, the coexistence with grazing animals suggests no significant inhibition on microbialite growth, thereby calling into question the decline of microbialite as a result of metazoan evolution. Varying sedimentation rates are likely important in controlling the distribution of thrombolite-stromatolite packages in the geological record, given the importance of this factor at Bacalar.
\end{abstract}

\section{INTRODUCTION}

Microbialites are organo-sedimentary structures that form in modern marine and nonmarine environments through the accretion of sediment by benthic microbial communities (e.g., Burne and Moore 1987). Based on their internal fabric, microbialites are subdivided into two distinct groups as per Shapiro (2000): (1) stromatolites, which show internally laminated mesostructures (as originally defined by Kalkowsky 1908), and (2) thrombolites, distinguished by their nonlaminated and clotted mesostructrue (Aitken 1967). Both form through a combination of trapping, binding, and/or authigenic precipitation by benthic microbial communities (Hofmann 1973; Riding 1999, 2011), and abiogenic processes (e.g., cementation).

Stromatolites, in particular, are among the oldest direct evidence of life, occurring in rocks as old as ca. 3.5 Ga (Hofmann 1973; Allwood et al. 2009). Unlike the Archean, where stromatolites have been observed as being limited to shallow-marine evaporitic basins (Lowe 1983; Allwood et al. 2006; Schopf 2006), by the Proterozoic, they were present in siliciclastic nearshore, intertidal (Schieber 1999), and carbonate platforms (Beukes 1987), as well as in epicontinental alkaline lakes and rivers, where the mats were commonly dolomitized and silicified (Buck 1980). Morphologically, these ranged from domes and simple columns to elaborately branched and bulbous structures. There were two major periods of diversification, the first during the Paleoproterozoic (2500$1650 \mathrm{Ma})$, and the second during the latter stages of the Mesoproterozoic $(1350-1000 \mathrm{Ma})$

By the late Neoproterozoic and early Paleozoic, there was a sharp decline in stromatolite diversity (Fischer 1965; Awramik 1971, 1991; Walter and Heys 1985; McNamara and Awramik 1992; Schopf et al. 2007). The cause of the decline remains controversial but factors such as the grazing and burrowing of mats by metazoans, competition for nutrients, substrate competition, and compositional changes in seawater chemistry may all have been contributory factors (Fischer 1965; Pratt 1982; Riding 1997). For instance, the decline is coincident with a major change in biota, the advent of grazing and burrowing organisms (Garrett 1970), and the onset of calcifying metazoans (Wood et al. 2002). Moreover, as the carbonate saturation state of the oceans changed there was a simultaneous decrease in the efficiency by which the stromatolitic layers accreted. Thus, it is possible that the abundance and the environmental diversity of stromatolites in the rock record is directly linked to marine carbonate saturation states (Grotzinger 1990, 1994; Grotzinger and Knoll 1999; Ridgwell and Zeebe 2005).

At the end of the Precambrian, and into the early Phanerozoic, thrombolites became important, and in places, even the dominant type of microbialite. There are several, not necessarily mutually exclusive, models regarding the factors leading to the expansion of thrombolites. Walter 




FIG. 1.-Map of the study area, Laguna Bacalar, which is located in southeastern Quintana Roo, Mexico. x, sampling locations. Samples Bac 110113, Th-St1, and stromatolite were collected from location 1. Water samples were collected from various locations; the cenote samples come from location 2 (Cenote Azul); samples R1-4 came from location 3; samples of spring and vent water came from location 4; and RM1 and RM2 were from location 5. The core samples Th-St2 were collected from location 3 .

and Heys (1985) first attributed the rise in their abundance to burrowing in preexisting stromatolites, while others proposed a switch in modes to benthic microbial communities mediating carbonate precipitation and early diagenetic modification (Shapiro 2000; Arp et al. 2001; Planavsky et al. 2009), and to the diversification and evolution of foraminifera (Bernhard et al. 2013). Microbialites, in general, were gradually replaced by reefs constructed of crustose red algae, calcareous sponges, and/or coelenterates (Golubic 1994), yet there are marine settings and short time periods where abundant microbialites persisted throughout the Phanerozoic.

An understanding of how modern microbialites grow, and what factors control their accretion, can provide us with a foundation from which to assess their changes in the rock record. The recently discovered microbialites from Laguna Bacalar, Quintana Roo, Mexico are some of the largest freshwater examples yet observed. Additionally, the microbialites display stromatolitic (internal lamination) and thrombolitic (internal clotting) fabrics, which affords a unique opportunity to explore the factors controlling both microbialite mesostructures. Lastly, these microbialites appear to be actively accreting alongside grazing animals. Little is known of these microbialites, as only the giant Holocene samples have been studied with the aim of assessing their ability to record accretionary rates (Gischler et al. 2008). The relationship that exists between microbialites and grazing organisms and the lake conditions that facilitate such abundant growth are yet to be determined. This paper considers the relationship between the environmental conditions of Laguna Bacalar and the composition of the microbialites, with the aim being to gain new insight into their PrecambrianPhanerozoic decline. 


\section{CHETUMAL E $16-4-7$}
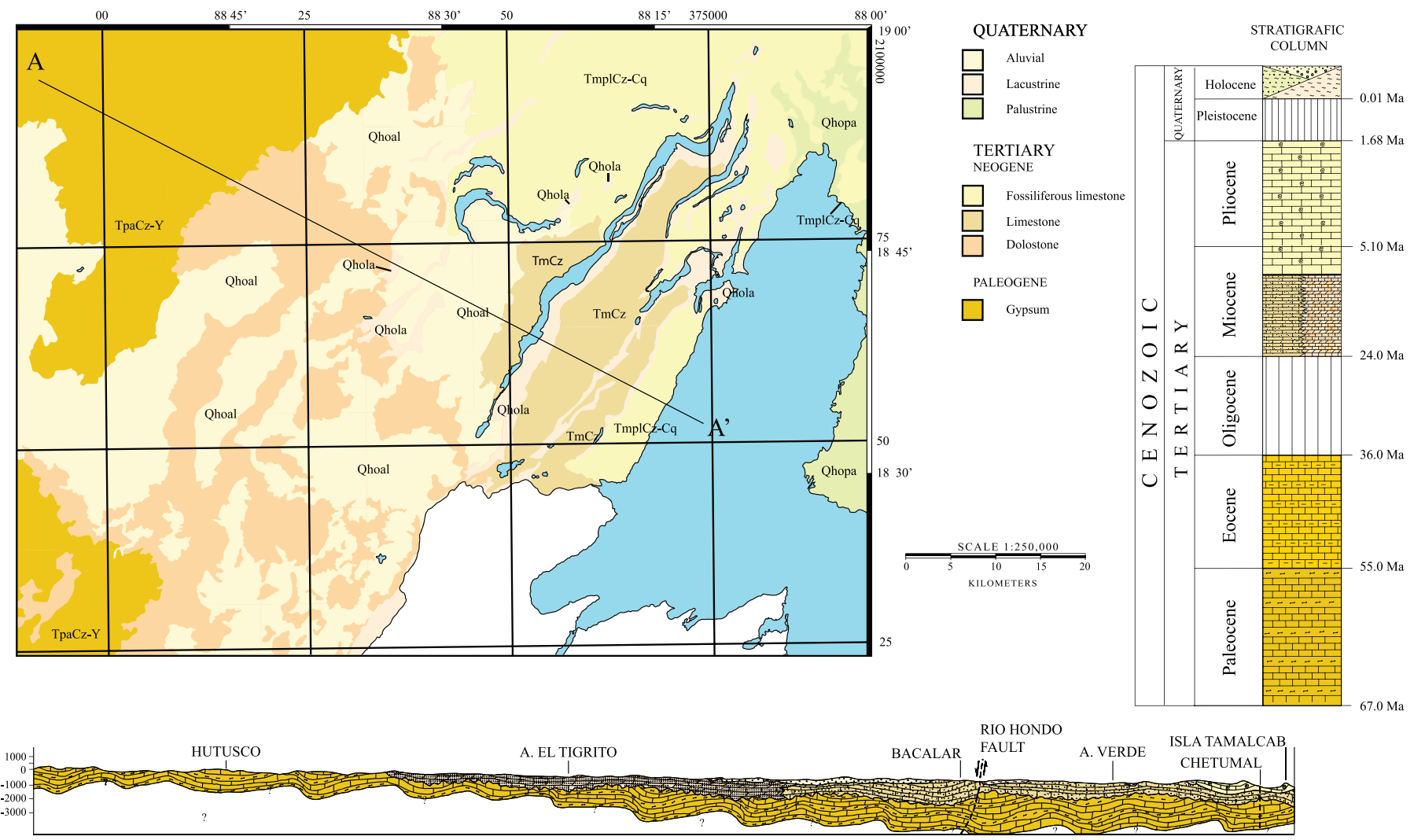

FIG. 2.-Geological map of southern Quintana Roo with cross section through Laguna Bacalar, modified from SGM (2005). Carta Geologica 1:25000, hoja E16-4 (Chetumal). Mexico: Servicio Geológico Mexicano.

\section{STUDY AREA}

Laguna Bacalar is a lake located in the southeastern part of Quintana Roo, Yucatan Peninsula, Mexico (Fig. 1). The Peninsula is characterized by its massive carbonate platform composed of limestone, dolomite, and evaporites, and by its extensive underground karstic system (Perry et al. 2002). The age of the platform ranges from Cretaceous to Holocene with the bedrock becoming younger toward the north (Hodell et al. 2004; Perry et al. 2009; Bauer-Gottwein et al. 2011; Perez et al. 2011). The regional geology has been subdivided into six different hydrogeochemical-physiographical zones: (1) Chicxulub Sedimentary Basin, (2) Cenote Ring, (3) Pock-Marked Terrain, (4) Ticul fault zone, (5) Holbox Fracture zone-Xel-Ha Zone, and (6) the Evaporite Region where Laguna Bacalar is found (Fig. 1; Perry et al. 2002).

Outcrops from Bacalar, and the banks of the Rio Hondo, are predominantly Miocene in age and separated by an Eocene ground fault, which is aligned subparallel to the southern Caribbean coast. The faulting was the result of distinct tectonic events during the Late Cretaceous and Pliocene period, and the formation of faulted basins (Fig. 2) (Díaz 2005; López et al. 2005; Bauer-Gottwein et al. 2011). Such basins are presently occupied by Laguna Bacalar, which is $\sim 2 \mathrm{~km}$ wide, $\sim 50 \mathrm{~km}$ long, an area of $\sim 3.1 \mathrm{~km}^{2}$, and an elevation of 1.5 meters above sea level (Gamboa-Perez and Schmitter-Soto 1999; Conagua 2002; Gischler et al. 2011). The lake receives an average annual precipitation of $1367 \mathrm{~mm}$ (Servicio Meteorológico Nacional 2000) and is fed from the north by karstic waters from the cenote Xul-Ha (Fig. 1). Microbialites are found predominantly on the western shores, spanning approximately $10 \mathrm{~km}$ from the northern end of Xul-Ha. No microbialites were found in Xul-Ha, or past the town of Bacalar.

\section{METHODS}

Collection of Samples

Sediment Samples. - A variety of microbialite samples, ranging in size and morphology, were collected from Laguna Bacalar during the summer of 2011 and winter of 2012. A microbialite core sample measuring $32 \mathrm{~cm}$ in length and $5 \mathrm{~cm}$ in diameter was collected with the use of a custom sediment corer. Lake sediments, and macrofauna (bivalves and gastropods), were also collected. All samples were reposited at the University of Alberta.

Water Samples.-Water samples were collected directly from the lake using a $60 \mathrm{ml}$ sterile syringe, and then filtered through a $0.2 \mu \mathrm{m}$ micropore filter. Duplicate samples were stored in polycarbonate sample bottles and immediately refrigerated. From the duplicates, one sample was treated with analytical grade $\mathrm{HNO}_{3}(8 \mathrm{~N})$ to a final concentration of $10 \% \mathrm{v} / \mathrm{v}$ for cation analysis, while the other was left unacidified for anion analysis. In situ $\mathrm{pH}$ measurements were taken with a Beakman $\Phi 295$ $\mathrm{pH}-$ Meter fitted with a Thermo Scientific Oron $\mathrm{pH}$ Probe. Water hardness for each of the latter samples was determined in situ with a Hach Digital Titrator.

\section{Aqueous Geochemistry}

All aqueous geochemical analyses were performed at the University of Alberta. $\mathrm{Cl}^{-}$analyses of the lake water were performed using a Dionex DX600 Ion Chromatograph (IC). Acidified water samples were analyzed using a Perkin-Elmer Elan 6000 quadrupole ICP-MS. The 
TABLE 1.-Trace element concentrations of the lake water.

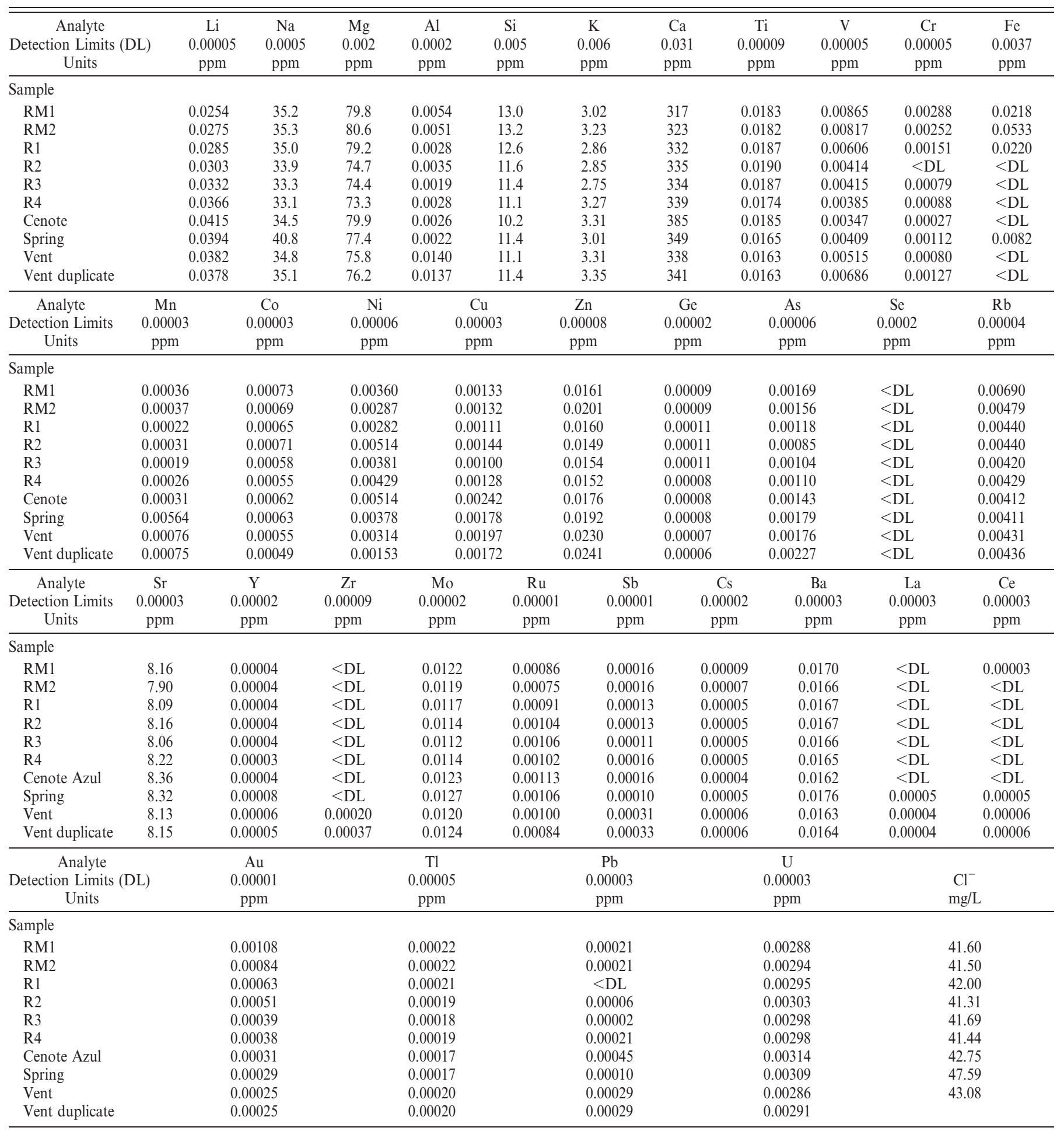

parameters used were as follows: RF power $1200 \mathrm{~W}$, peak-hopping acquisition, and $50 \mathrm{~ms}$ dwell time. Results were calibrated against a standard containing $10 \mathrm{ppm}$ of $\mathrm{Br}$, In, and Sc. The relative standard deviations $(2 \sigma)$ for $\mathrm{Na}$ and $\mathrm{Fe}$ were between $3 \%$, for $\mathrm{Al}$ and $\mathrm{Zn}$ they were $0.35 \%$, and between $0.005 \%$ and $0.06 \%$ for most other analyzed elements. Detection limits were between $10 \mathrm{ppb}$ (e.g., Ru, Ga) and 0.31 ppm (e.g., Ca).

\section{Solid-Phase Mineralogical-Geochemical Analyses}

All solid-phase mineralogical and geochemical analyses were conducted in the laboratories at the University of Alberta.

Major Element Geochemistry.-The analyses of major elements were performed on polished sections (1 mm thick) using a JEOL 8900 



FIG. 3.-Stromatolite images, including hand and field samples. A) Stromatolites (5-15 $\mathrm{cm}$ wide) are observed embedded on the surface of the larger thrombolitic stromatolites. The stromatolite samples coalesce with each other to form larger structures (contrast and brightness were modified). B) Domal stromatolites displaying a dark-gray coloration, and a smooth outer exterior. C) Stromatolite (5-15 wide) removed from the larger thrombolitic stromatolites displays internal lamination and a fibrous texture. D) Cross section of a stromatolite with distinct internal lamination made up of dark and light bands; the fibrous texture can also be observed.

Microprobe ( $15 \mathrm{kV}$ accelerating voltage, $5 \mu \mathrm{m}$ beam diameter, and $15 \mathrm{nA})$. The synthetic crystals used to calibrate the instrument included sphalerite $(\mathrm{S})$, apatite $(\mathrm{P})$, dolomite $(\mathrm{Ca}: \mathrm{Mg})$, willemite $(\mathrm{Mn})$, calcite $(\mathrm{Ca})$, barite $(\mathrm{Ba})$, strontianite ( $\mathrm{Sr}$ ), siderite (Fe), and albite (Na) (as per Jarosewich 2002).

Trace Element Geochemistry.-Trace elements were analyzed in situ using a Perkin-Elmer Elan 6000 quadrupole ICP-MS coupled to a New Wave UP-213 laser ablation system. Samples were ablated using identical parameters: spot size $(30 \mu \mathrm{m})$, repetition rate $(5 \mathrm{~Hz})$, and energy density $\left(\sim 13 \mathrm{~J} / \mathrm{cm}^{2}\right)$, RF power $(1200 \mathrm{~W})$, peak-hopping acquisition, and dwell time $(50 \mathrm{~ms})$. Quantitative results were calibrated against the NIST SRM612 internal glass standard, and normalized to [Ca], previously determined by electroprobe analysis. Data reduction and concentration determination were obtained using GLITTER ${ }^{\circledR}$ laser ablation software.

Bulk Trace Element Geochemistry.-For each sample, a mass of $10 \mathrm{mg}$ was ground and dissolved in screw-top Teflon ${ }^{\circledR}$ bombs (Savillex ${ }^{\circledR}$ ) using $\mathrm{HF}$ and $\mathrm{HNO}_{3}$. The samples were left to react at $130^{\circ} \mathrm{C}$ for 48 hours. Subsequently the temperature was increased to $140^{\circ} \mathrm{C}$ in order to completely dry the samples. These were then treated with HCL and
$\mathrm{HNO}_{3}$ for 24 hours at $130^{\circ} \mathrm{C}$, and dried at $140^{\circ} \mathrm{C} . \mathrm{HNO}_{3}$ was then added and allowed to react with the samples at $130{ }^{\circ} \mathrm{C}$ for two hours. Samples were then analyzed using a Perkin-Elmer Elan 6000 quadrupole ICP-MS as above.

Stable C- and O-Isotope Analysis.-Stromatolite (St) and thrombolitic stromatolite (Th-St) microbialites were analyzed, as well as lake sediment, gastropod, and bivalve shells. Samples were ground in an agar mortar and pestle, treated with $\mathrm{H}_{2} \mathrm{O}_{2}(50 \%)$ for $48 \mathrm{~h}$ to eliminate all organic matter, rinsed three times with ultrapure water, and dried overnight in a vacuum oven at $30^{\circ} \mathrm{C}$. Carbon and oxygen isotope compositions were determined through analysis of cryogenically extracted $\mathrm{CO}_{2}$ produced by $\mathrm{H}_{3} \mathrm{PO}_{4}$ digestion (McCrea 1950). The $\mathrm{CO}_{2}$ was analyzed using an internal standard NBS90 in a Finnigan Mat 252 Mass Spectrometer. The results were reported in $\delta$ notation with respect to V-PDB and SMOW for carbon and oxygen, respectively (Craig 1957, 1961).

Scanning Electron Microscopy (SEM).-Grain mounts were sputter coated with gold, and observed using a Zeiss EVO MA 15 and JEOL630F. The analyses were performed at accelerating voltages of 5 

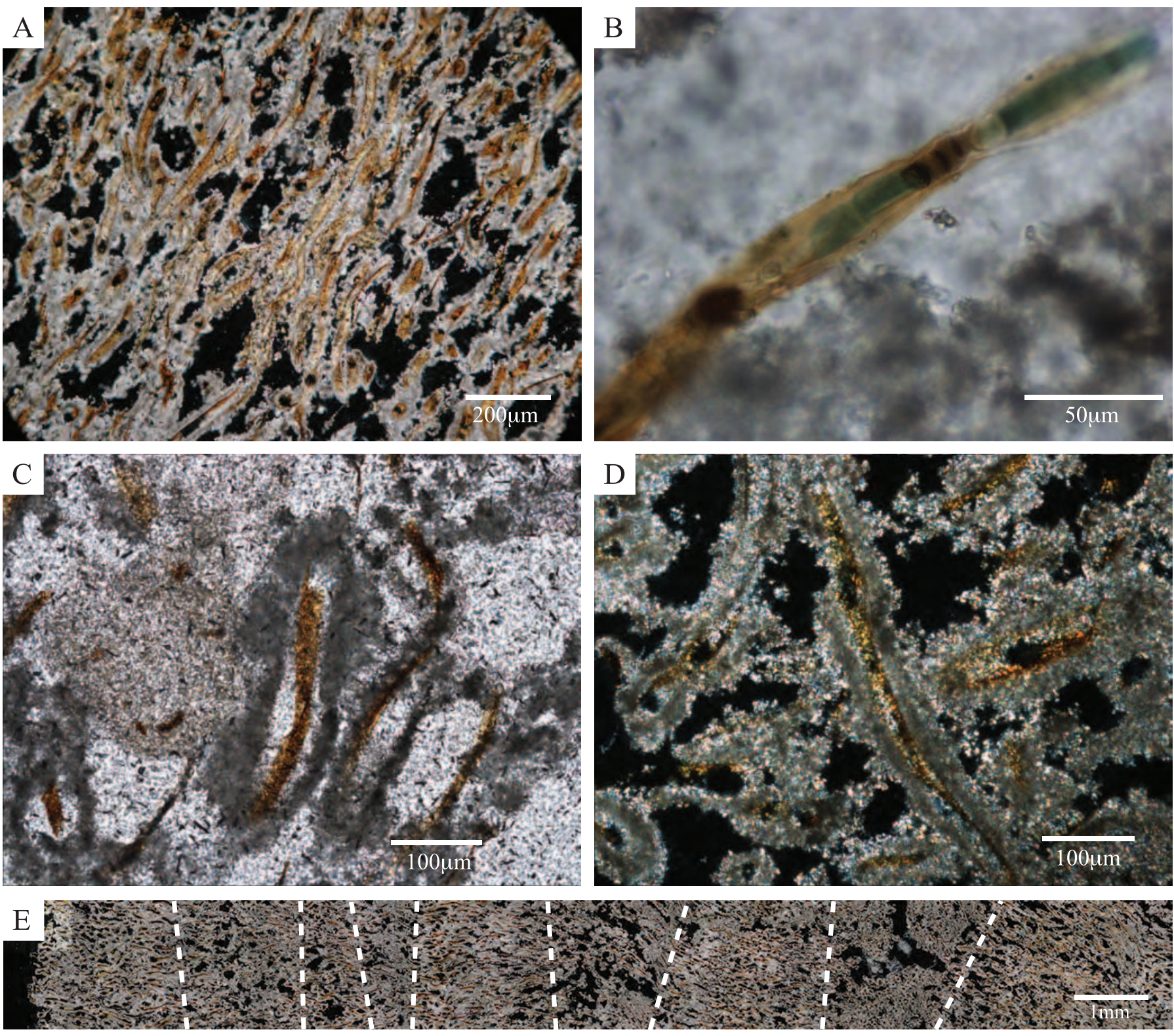

FIG. 4.-Petrographic images of stromatolites under cross- (XPL) and plane-polarized light (PPL). A) Microbial filaments under XPL displaying brownish coloration Lengths of the filaments are variable, and the widths average between 10 and $30 \mu \mathrm{m}$. Individual filaments are surrounded by calcite, predominantly micrite, and cemented together by microspar. The voids formed by the decomposition of the bacterial filaments are infilled by varying degrees of microspar, always precipitating inward B) Bacterial filament under PPL that still retains internal segmentation and green pigmentation. C) Microbial filament under PPL surrounded by micrite (gray translucent appearance). D) Microbial filament under XPL, displaying brownish coloration, surrounded by micrite, and infilled by microspar to create a microbialite mold. E) Petrographic cross section of an entire stromatolite under XPL. Banding is observed to be the result of sections having high abundance of bacterial filaments-molds and little porosity (designated as P-lamina), preceded by sections with higher porosity and much less bacterial abundance (designated as U-lamina).

and $20 \mathrm{kV}$ and a working distance ranging from 6 to $19 \mathrm{~mm}$ (see individual image for specifics). The textural relationships between the extracellular polymeric substance (EPS), and authigenic mineral phases, organisms present, and grain types and sizes were observed.

X-Ray Microtomography.-One microbialite sample displaying internal lamination and dome morphology $(5 \mathrm{~cm}$ in length, $2 \mathrm{~cm}$ in width and height) was analyzed using a SkyScan 1172 Desktop X-ray Microtomograph with an X-ray microfocus tube operating at $110 \mathrm{kV}$ and $250 \mu \mathrm{m}$, resulting in a $5 \mu \mathrm{m}$ focal spot and a $33 \mu \mathrm{m}$ resolution. The sample was scanned every $0.5^{\circ}$ in its entirety and the images processed using the application CT-Analyzer. The relationship between the cyanobacteria and the internal laminae was documented.

XRD Analyses.-Five microbialite samples from different locations in Laguna Bacalar were powdered using an agar mortar and pestle. Powder was less than $10 \mu \mathrm{m}$ from which 1-2 $\mathrm{g}$ were placed on the holders and analyzed using a Rigaku Ultima IV X-Ray diffractometer. Data was processed and minerals identified using JADE 9.1 software and the ICDD and ICSD databases. 

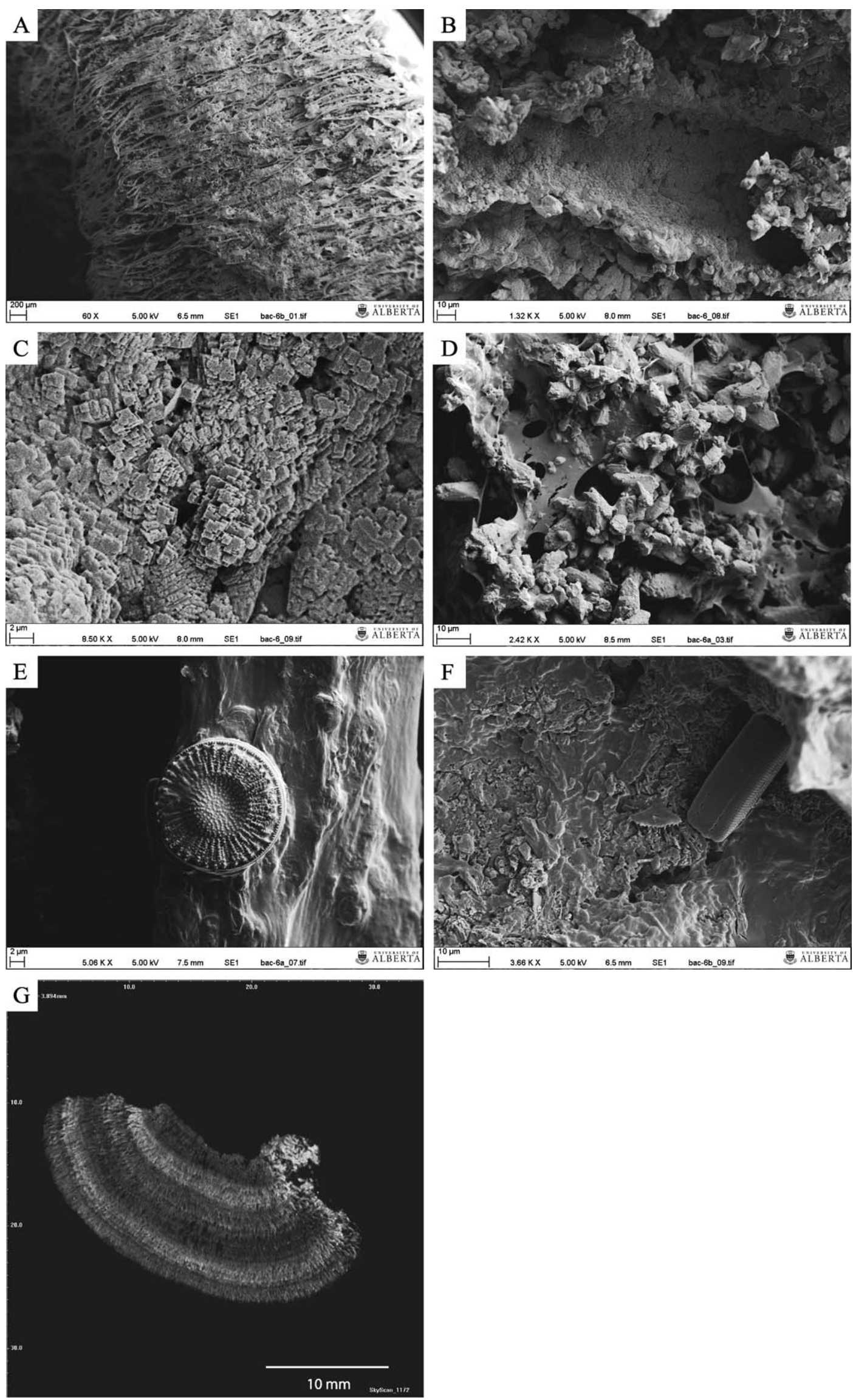


\section{Petrography}

Petrographic thin sections of various microbialites displaying stromatolitic and thrombolitic textures were prepared and examined using transmitted light microscopy. The grain type and size, mineral and textural composition, and their relationships with the organisms present were recorded.

\section{RESULTS AND DISCUSSION}

\section{Lake Water Chemistry}

Measured $\mathrm{pH}$ values of the surface waters of Laguna Bacalar varied between 7.7 and 8.2. The dominant cations in the lake waters were $\mathrm{Ca}^{2+}$ (332.5 ppm) and $\mathrm{Mg}^{2+}(80.8 \mathrm{ppm})$, while the average $\mathrm{Cl}^{-}$concentration was $42.44 \mathrm{mg} / \mathrm{l}$ (see Table 1 for complete water chemistry). These values are in agreement with those reported by Gischler et al. (2008). They determined that the water originating from the Xul-Ha sinkhole was supersaturated with respect to calcium carbonate due the flow path of the karstic water through the carbonate bedrock of the Yucatan Peninsula, and the change in partial pressure of $\mathrm{CO}_{2}$ due to degassing upon reaching the surface at Xul-Ha.

\section{Microbialite Composition and Texture}

Microbialites displayed a variety of sizes and morphologies, but in general can be classified into two groups based on their internal fabrics or mesostructures: (1) stromatolites and (2) thrombolitic stromatolites. It is these textures that can provide us with insight into the various factors controlling microbialite growth.

Stromatolite Texture.-These microbialites are mainly observed on the outer surfaces of larger thrombolitic stromatolites (Fig. 3A). They display a dark-gray color and smooth domal morphology (Figs. 3A, B). Cross sections reveal very well defined laminae with an internal fibrous texture (Figs. 3C, D), presumed to be the result of filamentous cyanobacteria. Petrographically, stromatolites are composed entirely of calcite (see Supplemental Data for XRD analysis) and cyanobacterial filaments. The filaments (brown in color) were $\sim 10-30 \mu \mathrm{m}$ in width, with variable lengths (Fig. 4A). Some still display internal structure and green pigmentation (Fig. 4B). Micrite-sized calcite is precipitated around the individual filaments resulting in the formation of molds $\sim 20 \mu \mathrm{m}$ thick (Fig. 4C). As the cyanobacteria within the molds begin to decompose, secondary precipitation occurs in the form of microspar infills. The existing micrite is used as a substrate from which growth is observed to occur inward, even while filaments are still present (Fig. 4D). Subsequently, the molds are cemented together by microspar as calcite precipitation continues (Fig. 4E). SEM images further show the highly calcified cyanobacterial filaments (Fig. 5A), as well as the individual molds that are composed of microspar (Fig. 5B) and micrite (Fig. 5C). Also of importance is the presence of abundant EPS covering calcite grains (Fig. 5D), cyanobacterial filaments (Fig. 5E), and diatoms (Fig. 5E, F).

Internal lamination results from the rhythmic layering of laminae containing higher abundances of cyanobacterial filaments-molds (which we refer to here as P-laminae after Konhauser et al. 2004), preceded by laminae having greater porosity and lesser cyanobacterial abundance (called U-laminae) (Figs. 4E, 5G). Due to the continuous precipitation of calcite, the cyanobacteria must migrate upward in order to obtain the necessary photosynthetic active radiation (generally between 400-700 nm wavelength; Howard 2012). It is such migration that results in the generation of porosity, as seen in the U-laminae.

A lack of detrital grains suggests that growth was solely through the precipitation of calcite. This very much differs from modern marine stromatolites in the Bahamas in which cyanobacterial filaments are able to intertwine and incorporate detritus within their EPS to form a cohesive mat-like structure. There are several microbially mediated processes that can drive carbonate precipitation (e.g., Simkiss and Wilbur 1989; Riding 2006a; Planavsky et al. 2009). Photosynthetic $\mathrm{CO}_{2}$ uptake can locally cause an increase in $\mathrm{pH}$ and the carbonate anion $\left(\mathrm{CO}_{3}{ }^{2-}\right)$ concentration. This mode of carbonate precipitation is consistent with formation of filament molds within a cyanobacterial sheath. In other environments, anaerobic heterotrophy, such as bacterial sulfate reduction, plays an important role in generating alkalinity (eg., Visscher et al. 1998; Petrash et al. 2012). Indeed, in marine stromatolites much more calcium carbonate is precipitated within the aphotic zone of intertidal mats on cyanobacterial remains than in the euphotic zone dominated by living cyanobacteria (Chafetz and Buczynski 1992). However, in Laguna Bacalar, there is minimal sulfate in the lake water. Additionally, the presence of EPS provides nucleation sites for mineral precipitation, while also potentially absorbing essential elements utilized by the cyanobacteria (Pentecost 1978; Pentecost and Riding 1986; Merz-Preifi 2000; Braissant et al. 2003; Jones et al. 2005; Dupraz et al. 2009; Perri and Spadafora 2011; Petrash et al. 2011). Collectively, these processes facilitate the formation of the cyanobacterial molds (e.g., Fig. 4C).

Thrombolitic Stromatolite Textures.-These microbialites tend to reach sizes up to several meters. They typically display domal morphology, having either a smooth or a pitted exterior (Fig. 6A-C). They appear lightcream in coloration, although those subaerially exposed have a darker-gray color (Fig. 6C). Their close proximity to each other often results in their coalescence (Fig. 6C). Bivalves (identified as Dreissena sp.) were found embedded on their outer surface (Fig. 6D), while gastropods (Pomacea sp.) lay dispersed around the microbialites (Fig. 6E). Microbialites were also observed utilizing several substrates for their growth, including mangrove roots (Fig. 6F). Internally, domal thrombolitic stromatolites have both stromatolitic and thrombolitic mesostructures (Fig. 7B-D). Laminae, similar to those found in stromatolites, were observed predominantly at the base and uppermost parts of the sectioned samples (Fig. 7B, C). A green, 1.2-cm-thick microbial mat was present in the upper part of the structure (arrow e; Fig. 7B), but $\sim 2-3 \mathrm{~mm}$ beneath the outer mineralization zone (i.e., endolithic growth). The porosity varied and was dependent on the internal texture: zones having stromatolitic textures were found to have lower porosity (Fig. 7C-E) compared to their thrombolitic counterparts (Fig. 7D). Bivalves were also seen cemented into the internal texture but exhibited no evidence of burrowing or boring (arrow b; Fig. 7B, E). Microbial molds similar to those in stromatolites were observed (Fig. 8A, B), as was internal lamination created by P- and U-laminae (Fig. 8C). Such internal texture is thought to be the result of growth exclusively through the precipitation of calcite.

In contrast, clotted laminae are composed primarily of rounded micrite grains that have no internal structure, and as such, are interpreted as

FIG. 5.-Stromatolite images. SEM images (Parts A-F). A) A high density of heavily mineralized microbial filaments. B) Bacterial mold having a smooth interior composed of micrite and microsparite calcite grains. C) Micrite grains smaller than $2 \mu \mathrm{m}$ composing the interior portion of the bacterial mold D) Calcite grains surrounded by EPS. E) Microbial filament surrounded by EPS with an embedded diatom. F) Diatom cell in the presence of EPS and calcite grains. G) X-ray microtomography of a complete stromatolite. Distinct layers can be observed, with varying densities of cyanobacterial filaments and porosity. 

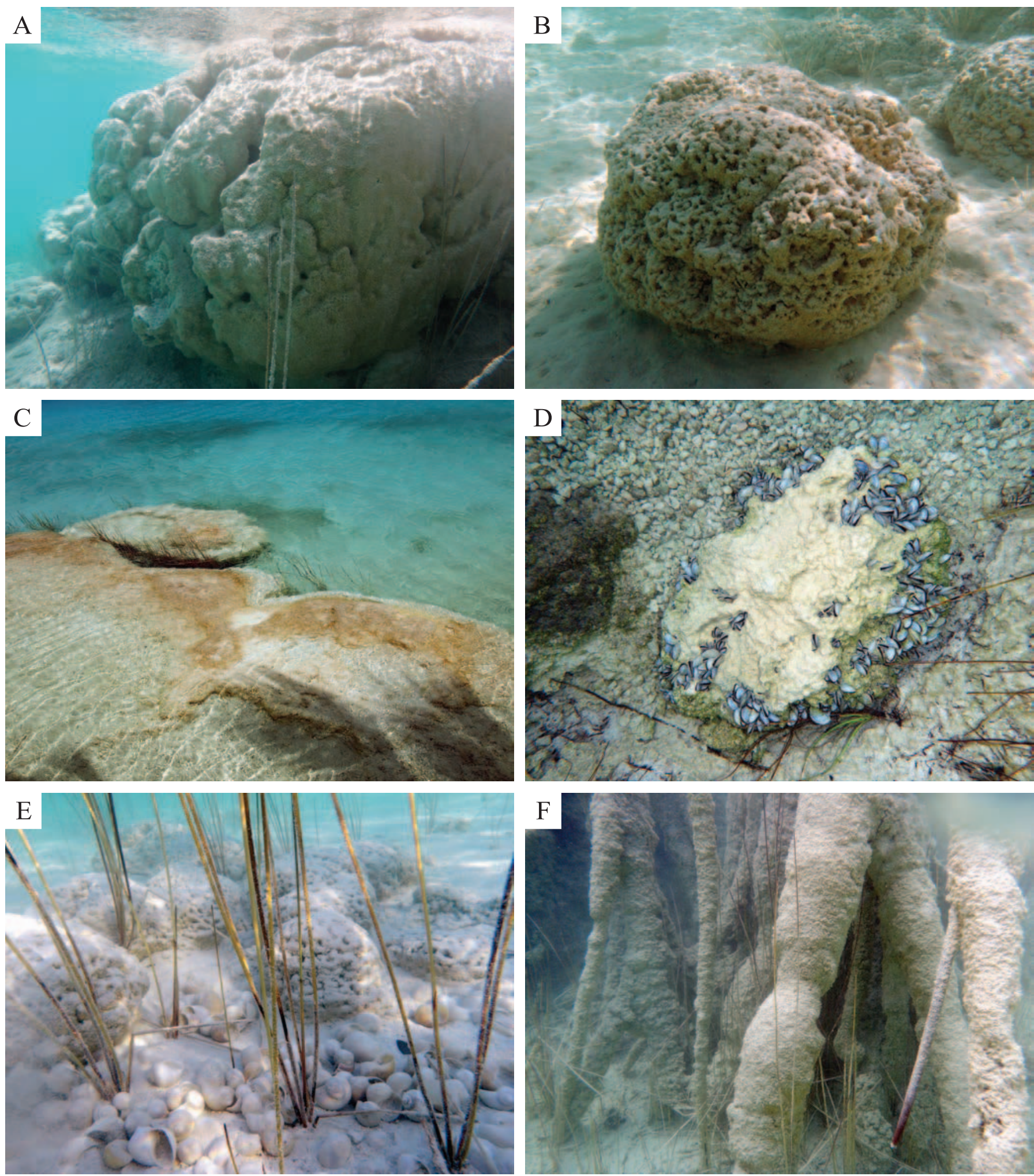

FIG. 6.-Field images of various thrombolitic stromatolites found in Laguna Bacalar ranging in size from meters to tens of meters (contrast and brightness modified). A) Thrombolitic stromatolites displaying domal morphology and a smooth exterior, with a cream coloration similar to that of lake sediment. B) Dome-shaped sample with a pitted outer texture. C) Meter-size thrombolitic stromatolites coalescing together to form larger structures. They also display domal morphology, and have a darker coloration where subaerially exposed. D) Bivalves found embedded on the outer surface of thrombolitic stromatolites. E) Thrombolitic stromatolites found growing in the presence of surrounding gastropods and mangrove shoots. F) Mangrove roots on the western shore being used as a substrate for the growth of microbialites. 

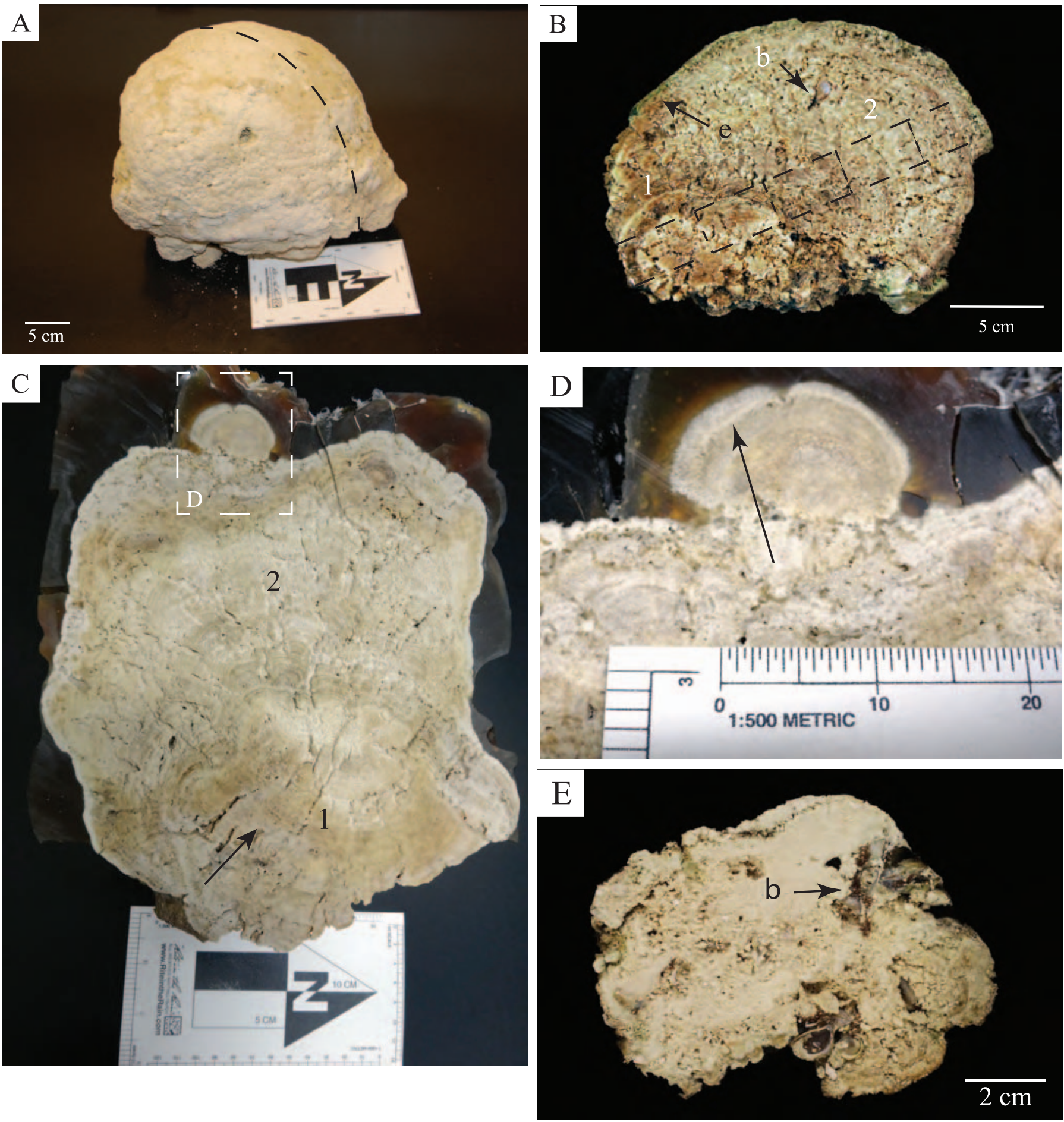

FIG. 7.-Microbialite displaying domal morphologies, with internal stromatolitic and thrombolitic texture. A) Domal thrombolitic stromatolites with a smooth exterior. B) Cross section of the microbialite in Part A. Internal stromatolitic lamination can be observed at the bottom-left (1) and top section (2). The middle section displays thrombolitic textures, as well as cemented bivalve shells (arrow b). A green endolithic algal mat is located at the top of the microbialite (arrow e). Dashed lines show where thin and thick sections were taken from. C) Cross section of larger microbialite displaying stromatolitic (1) and thrombolitic (2) textures (Bac 110113). Arrow indicates overturned stromatolite with concave laminae. Also present at the top of the sample are two apparent stromatolites that have coalesced and display complete internal lamination. D) Small microbialite containing internal laminae, with dark and light bands, found at the top of Part C (see arrow). E) Thrombolitic stromatolites (110324/7) displaying domal morphology and a number of bivalves, including their byssal threads (arrow b). 

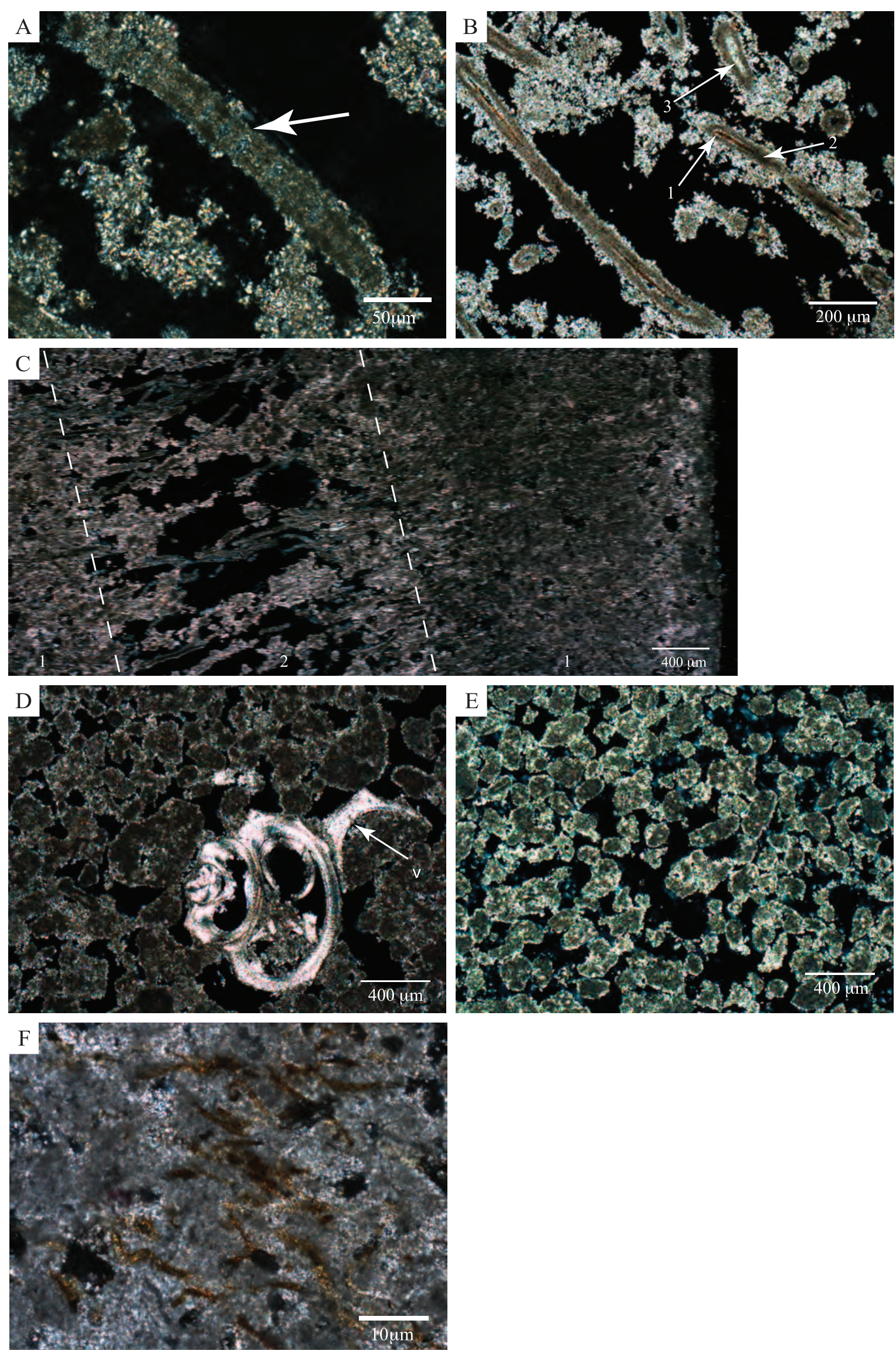

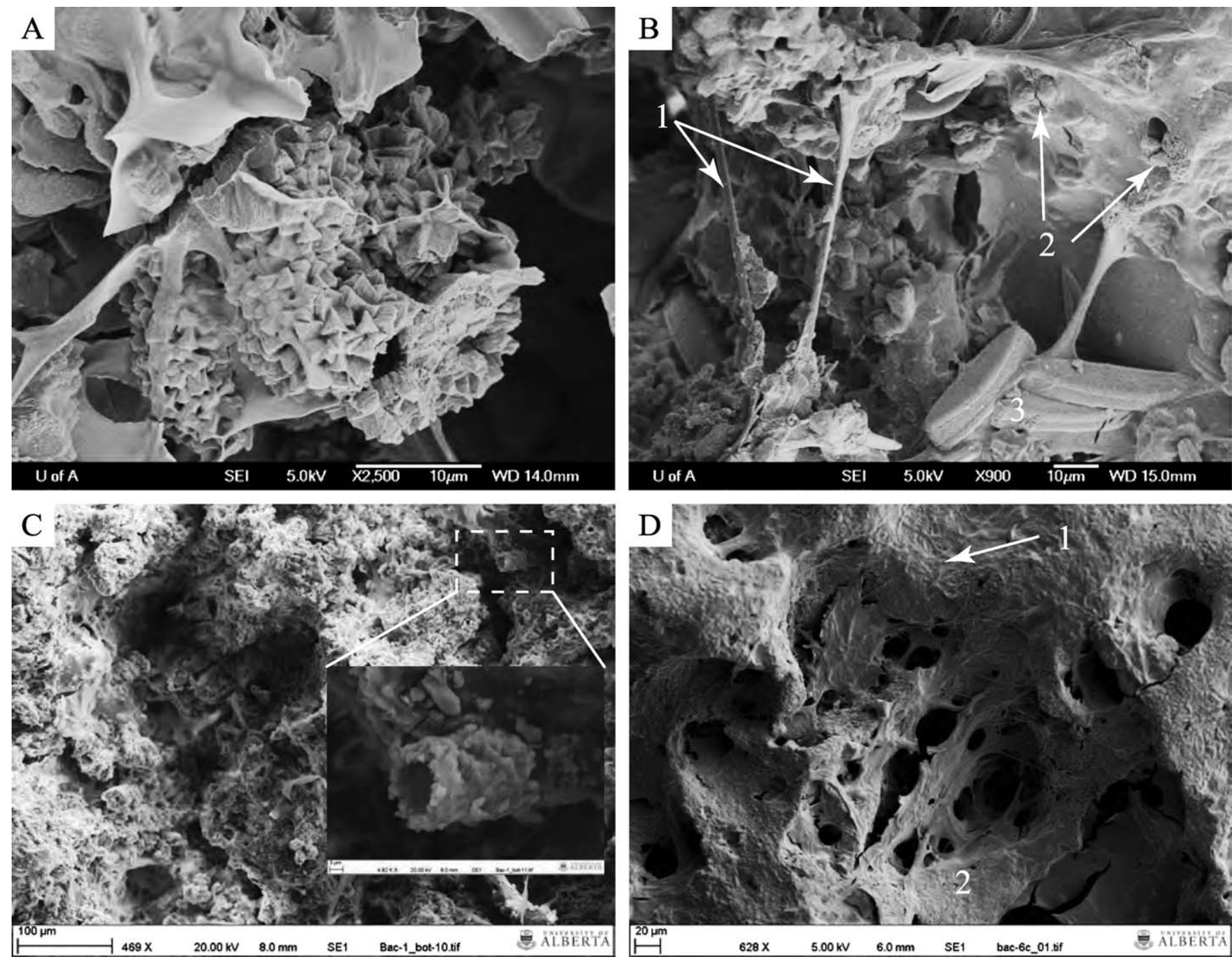

FIG. 9.-SEM images of thrombolitic stromatolites. A) Calcite grains displaying tetrahedral dipyramid morphology, consisting predominantly of micrite-size calcite. B) Bacterial filaments are observed having calcite grains still attached to their outer surface (arrow 1). Calcite grains are found to be either completely covered or surrounded by a smooth sheath of EPS (arrow 2). Intact diatom cells retaining their frustules and being surrounded or partially covered by EPS (3). C) Microbialite composed of EPS, calcite, and bacterial filament molds. Insert shows magnification of a single mold being surrounded by calcite grain and a void of the cyanobacterial filament. D) Microbialite section composed of abundant EPS. Cyanobacterial filaments are seen completely covered by EPS (arrow 1), as were calcite grains (2).

peloids (McKee et al. 1969), and cemented bioclasts (arrow v; Fig. 8D). The same rounded peloids were found in the lake sediment (Fig. 8E), suggesting that the peloids found in thrombolitic stromatolites are transported and not formed in situ. Cyanobacterial filaments within the clotted laminae were sparse, and appeared less mineralized than those found in the stromatolitic laminae (Fig. 8F). The presence of detrital peloids and bioclasts, and the lack of cyanobacterial filament molds, suggests that growth is the result of binding and trapping of grains by cyanobacteria, with subsequent precipitation driven by heterotrophic processes.

FIG. 8.-Petrographic images of thrombolitic stromatolites. A) Petrographic image of microbial mold under cross-polarized light (XPL). Internal structure is still visible, and has been replaced by micrite (gray translucent appearance, individual grains indistinguishable). Microspar (high-birefringence grains) calcite is observed infilling parts of the mold, as well as precipitating on the outer surface of the mold. B) Image under XPL showing microbial filaments (arrow 1) with a dark-brown coloration, surrounded by micrite (arrow 2) and infilled by microspar (arrow 3), which is also cementing together the bacterial filament molds. C) Transect of part of thrombolitic stromatolites under XPL displaying lamination. Laminae are observed having a high density of cyanobacterial filaments-molds (P-laminae) (1), preceded by a lamina having greater porosity and a lesser abundance of cyanobacterial filaments-molds (U-laminae) (2). D) Micrite peloids viewed under XPL showing their cementation secondary microspar. Also observed is a bioclast (arrow, v). E) Micritic peloids under XPL from the lake sediment. F) Microbial filaments under XPL displaying brownish coloration and much less mineralization. 

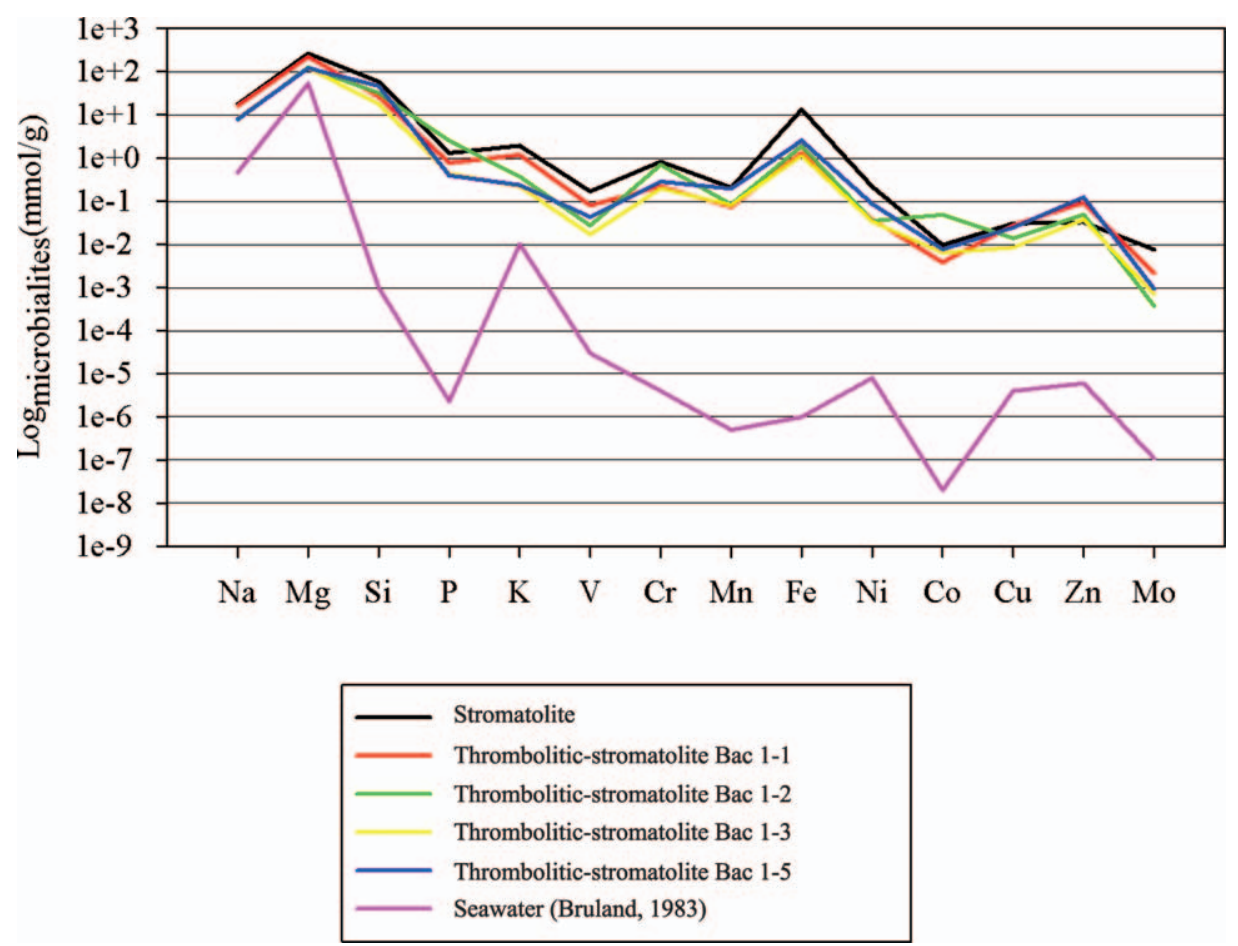

FIG. 10.-Elemental comparison of a stromatolite sample versus thrombolitic stromatolite samples (four samples). Seawater and Laguna Bacalar lake water are also provided as a comparison.

Interestingly, all of the observed microbialites appear to begin as stromatolites: this is observed in the overturned stromatolite at the base of Bac 110113 (Fig. 7C). As stromatolites grow their surface area increases, thereby allowing for more sediment (if available) to be deposited on their surfaces, and ultimately trapped. Those trapped grains are then cemented together by microsparite, most likely the result of EPSinduced precipitation. SEM images show the interaction between the individual grains and the EPS (Figs. 5, 9), as well as the presence of calcite grains with dipyramid morphology (Fig. 9A) that have previously been reported to preferentially grow in the presence of EPS (Buczynski and Chafetz 1991, 1993). As greater amounts of peloids are incorporated into the structure, the cyanobacteria migrate upward in order to obtain the necessary light, causing further trapping and binding of grains, and subsequent migration. This results in internal clotting, and the elimination of banding, due to the constant cyanobacterial movement that prevents the continuous precipitation of micrite in the horizontal. Such lamination reappears if sediment deposition decreases, either due to the decrease in current or due to the sheltering of the microbialite allowing time for micrite precipitation to occur (see arrow; Fig. 7D).

In summary, the textural and morphological differences observed between the microbialites can be attributed to the distinct growth mechanisms. Internal lamination is attributed to the precipitation of calcite by cyanobacteria while accretion occurs through the process of trapping and binding which results in internal clotting. These mechanisms, however, also appear to be dependent on the lake's current. Lamination is favored by calm lake conditions, in which no sediment is deposited upon the stromatolite's surface. Hence, calcite can be precipitated from the supersaturated waters, and lamination produced as the bacteria rhythmically migrate upward. In contrast, internal clotting is favored during relatively high-energy conditions in which detrital sediments are transported and deposited by the lake currents on the surface of microbialites, yet are not immediately removed. Such conditions are confirmed by suspended sediment in the water causing poor visibility. This allows sediments to be trapped and bound by the bacteria, which in turn, become incorporated into the microbialite structure. As a consequence of the deposited detrital sediment on microbialites, bacteria are continuously forced to migrate upward, further binding and trapping newly deposited sediment. This results in the clotted fabric, and prevents precipitation of calcite.

\section{Microbialite Geochemistry}

Elemental maps obtained from the microprobe analysis of the various microbialites (stromatolites and thrombolitic stromatolites) show low relative concentrations of $\mathrm{Fe}, \mathrm{S}, \mathrm{Mn}, \mathrm{Mg}$, and Si. Bulk ICP-MS values for individual samples were averaged and compared to those obtained through laser ablation. It was observed that the values differed depending on the analytical technique used (bulk versus laser ablation) but also whether or not they had been treated with or without $\mathrm{H}_{2} \mathrm{O}_{2}$ (Fig. 11). When stromatolites and thrombolitic stromatolites were compared, similarities in their elemental patterns were observed; however, stromatolites were enriched in certain elements $(\mathrm{Mg}, \mathrm{Si}, \mathrm{V}, \mathrm{Cr}, \mathrm{Fe}, \mathrm{Ni}, \mathrm{Mo}, \mathrm{Fe}$, Ni) (Fig. 10). We believe such disparities can be linked to the presence of cyanobacteria.

It is known that certain elements are essential for microorganisms. Some are needed for the synthesis of particular enzymes, while others are utilized as nutrients (Silver 1998; Silva and Williams 2001; Baptista and Vasconcelos 2006). Both types of microbialites found in Laguna Bacalar display very similar major and trace element patterns; however, they do differ depending on the lake waters in which they grow (i.e., they show some elemental enrichment factors, Fig. 10). This is not surprising given that cyanobacterial filaments and EPS are present in the microbialites, both of which have highly reactive surfaces that can facilitate sorption reactions (see Konhauser 2007 for details). Consequently the slight elemental differences between stromatolites and thrombolitic stromatolites may be attributed to the duration the cyanobacteria and its EPS remain in a given place. Specifically, during precipitated mediated growth (i.e., laminated), higher concentrations of essential nutrients are absorbed by cyanobacterial EPS due to their constant presence and slow migration. However, as the growth mechanism changes to that of trapping and 
A

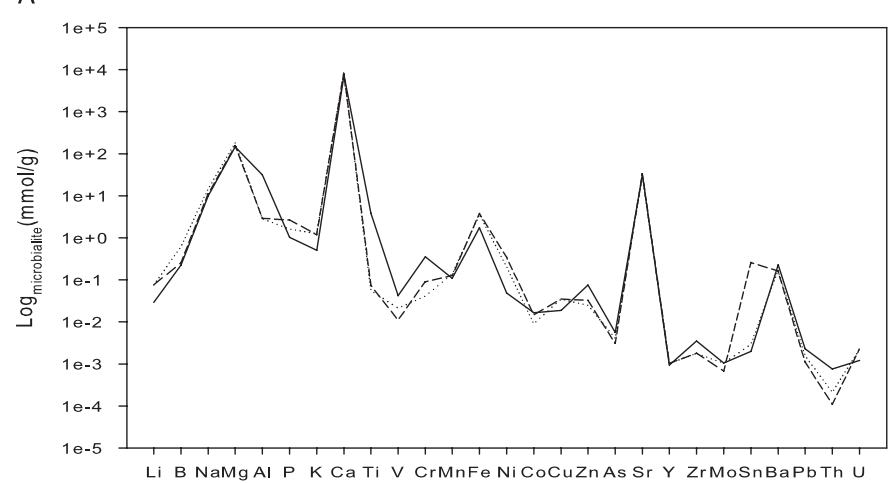

Li B NaMg Al P K Ca Ti V CrMnFe NiCoCuZnAs Sr Y ZrMoSnBaPbTh U

Average Thromb

Average Thrombolitic-stromatolite (bulk digest)

B

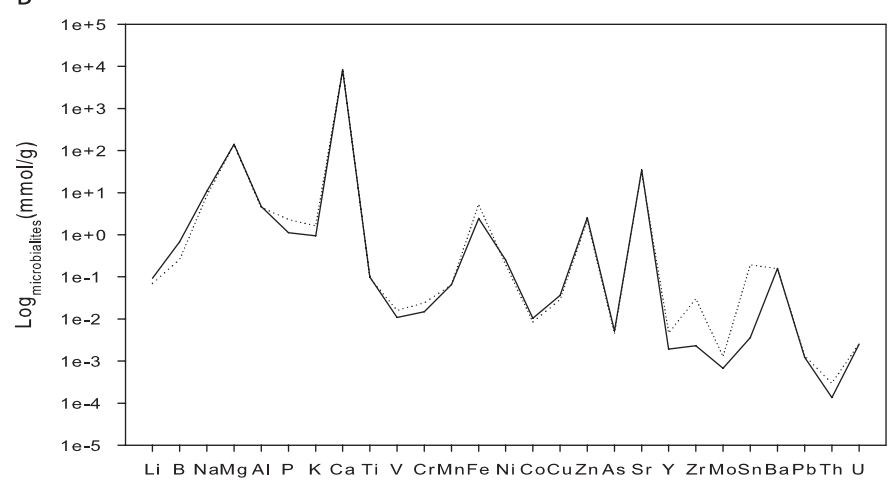

110326-2 Top (digested)

C

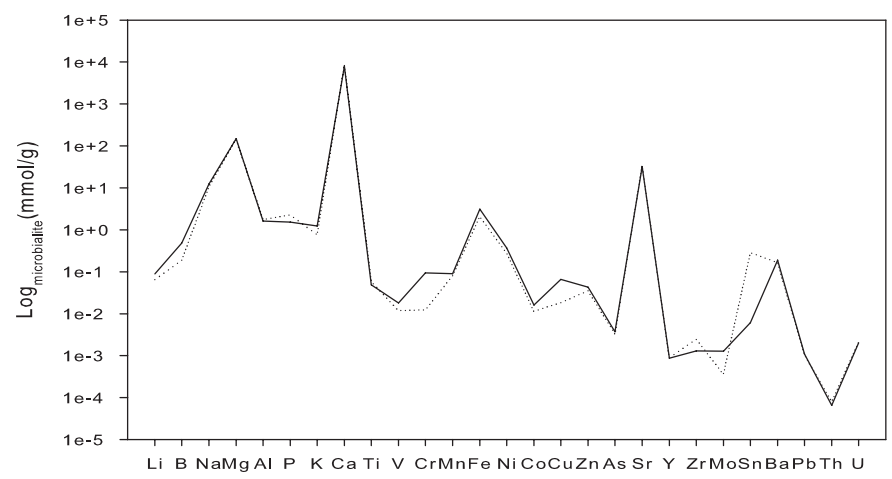

Bac 6 Top

Bac6 Top (digested)

FIG. 11.-Elemental graphs of stromatolites and thrombolitic stromatolites. A) Average measurements of thrombolitic stromatolite samples obtained from laser ICP-MS, bulk ICP-MS, and digested bulk ICP-MS. B) Thrombolitic stromatolites (St. 10326); comparison between digested and undigested bulk ICPMS measurements. C) Thrombolitic stromatolites (Bac 6); comparison between digested and undigested bulk ICP-MS measurements.

binding, cyanobacterial migration increases, causing their abundance at a given place and time to be become limited. Support for this idea comes from the observation that the microbialite samples containing organic matter have higher concentrations than those that had their organic content removed through the use of $\mathrm{H}_{2} \mathrm{O}_{2}$ (Fig. 11). Individual samples appear to have similar patterns that differ only in their concentrations, possibly in response to the presence or absence of cyanobacterial filaments. This suggests that while the elemental concentrations might differ as a consequence of cyanobacterial presence, the original signature is preserved in the microbialites even after the decomposition and disappearance of the bacteria and its EPS. As such the comparison of trace elements found in stromatolites, and in various sections of thrombolitic stromatolites potentially allow us to attribute the internal clotting to cyanobacteria even though the cells are not always preserved.

Carbonate $\delta^{13} \mathrm{C}$ isotope values can also provide insights into the role that different microbial processes played in driving calcium carbonate precipitation at Laguna Bacalar. Carbon and oxygen isotope data from microbialites, gastropods, bivalves, sediment, and lake water are presented in Table 2 and plotted in Figure $12 . \delta^{13} \mathrm{C}_{\mathrm{PDB}}$ isotope values of thrombolitic stromatolites have a range between $-0.30 \%$ and $-1.53 \%$. Bulk stromatolite samples were slightly more depleted, averaging $-2.03 \%$. Lake sediment ranged between $-1.46 \%$ and $-1.55 \%$. Gastropods and bivalves had the lowest values, averaging $-6.15 \%$ and $-4.40 \%$, respectively.

Cyanobacteria preferentially fix ${ }^{12} \mathrm{C}$ during photosynthesis due to the kinetic isotope effects during $\mathrm{CO}_{2}$ uptake (Park and Epstein 1961; O'Leary 1981; McConnaughey et al. 1997; Schidlowski 2000). Therefore, low $\delta^{13} \mathrm{C}$ carbonate isotope values in microbialites, relative to the lake DIC values, are linked to precipitation in an environment with inorganic carbon derived from organic matter remineralization (e.g., Andres et al. 2006). Positive $\delta{ }^{13} \mathrm{C}$ isotope values suggest carbonate precipitation driven, in part, by significant photosynthetic $\mathrm{CO}_{2}$ uptake, leaving behind a reservoir of positive $\delta^{13} \mathrm{C}$ bicarbonate. Foremost, preferential uptake of ${ }^{12} \mathrm{C}$-enriched carbon dioxide uptake creates a ${ }^{13} \mathrm{C}$-enriched microenvironment with an elevated $\mathrm{pH}$ (for review see Riding 2000, 2006a).

We compared microbialite and bivalve carbonate $\delta^{13} \mathrm{C}$ isotope values in order to gauge the effects that organic matter remineralization and photosynthetic carbon dioxide uptake played in driving carbonate precipitation. The bivalve carbonates can be assumed to have formed essentially synchronously with most of our microbialite samples (see discussion above), and hence, they track the lake DIC $\delta{ }^{13} \mathrm{C}$ values. Microbialite carbonates are consistently enriched relative to bivalves. Photosynthetic $\mathrm{CO}_{2}$ uptake driving the carbonate precipitation is the simplest explanation for this difference in carbonate $\delta^{13} \mathrm{C}$ values. It is important to note that when there are low concentrations of available $\mathrm{CO}_{2}$, cyanobacteria will take up $\mathrm{HCO}_{3}{ }^{-}$instead, which causes little isotopic discrimination (Stal 2000). This process makes it difficult to use the carbon isotopes to quantify microbial processes and to place constraints on the extent of $\mathrm{CO}_{2}$ uptake needed to trigger carbonate precipitation.

\section{Paleoenvironment Implications}

Based on our observations, we infer that varying sedimentation rates may similarly have been important in controlling the distribution of thrombolite-stromatolite packages in the geological record. It is possible that the diversification of carbonate biomineralization in the latest Neoproterozoic and earliest Phanerozoic could have increased the detrital carbonate sediment load on carbonate platforms. This higher detrital load could have led to a greater abundance of clotted microbialite textures, if the model outlined above for the formation of clotted textures at Laguna Bacalar is relevant to ancient thrombolites. Therefore, biological innovation that led to shifts in modes of carbonate formation could be another factor leading to an increase in thrombolite abundance in the Phanerozoic.

The results obtained from Laguna Bacalar microbialites suggest that water chemistry is the primary factor controlling microbialite growth. 
TABLE 2.-Carbon and oxygen isotope date from microbialites (stromatolites, St; thrombolitic stromatolites, Th-st), gastropods, bivalves, and water.

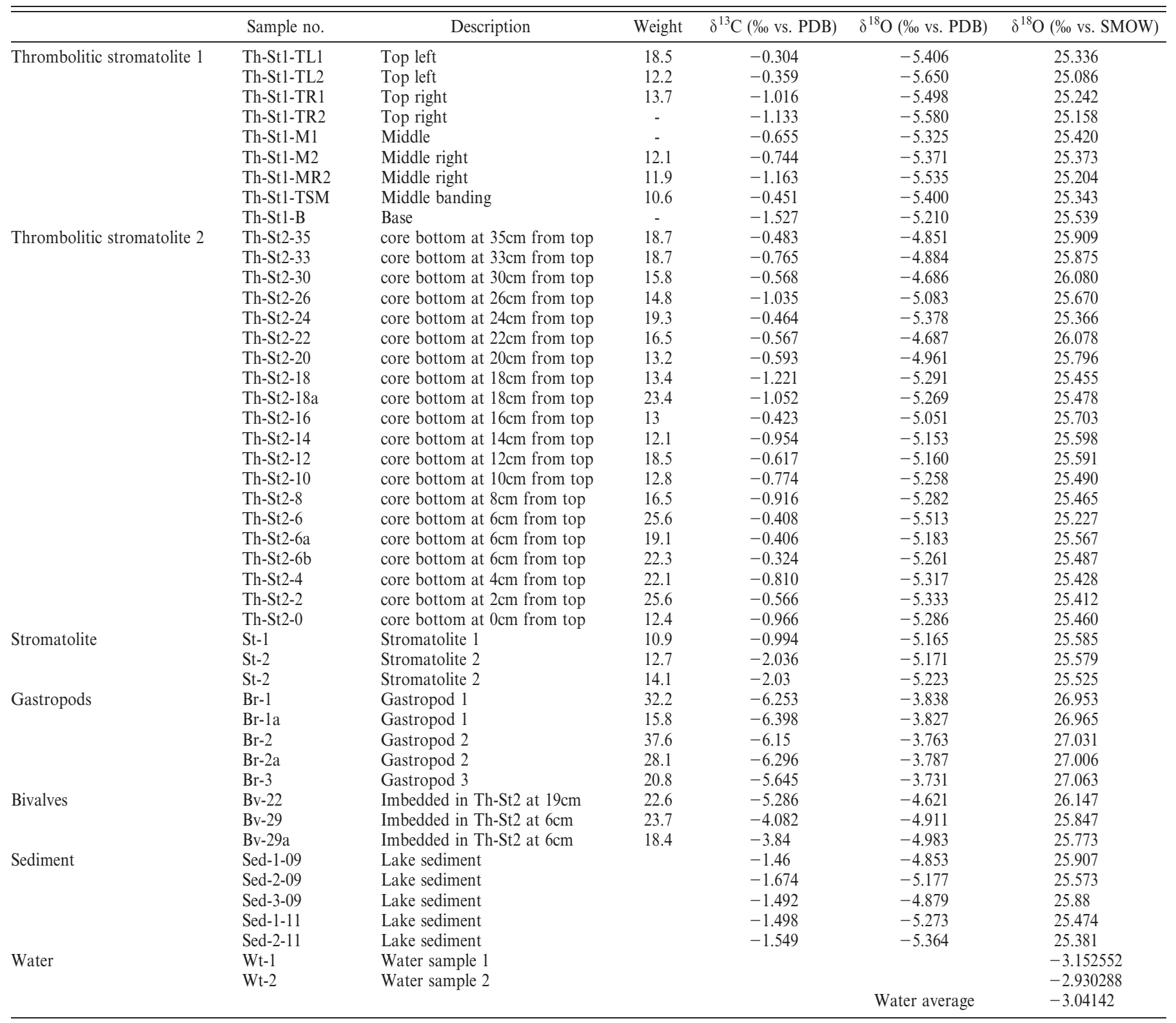

Supersaturation with regard to calcium carbonate facilitates organomineralization of calcium carbonate by cyanobacteria, and thus, formation of the microbialites. A reduction in the saturation state would likely result in the growth of a microbial mat, however the cyanobacteria forming the mat would likely be incapable of accreting to become a microbialite. The water surfacing at the Xul-Ha sinkhole is supersaturated with regard to calcium carbonate (Gischler et al. 2008, 2011), a consequence of its interaction with the carbonate bedrock in the karstic system and its degassing upon surfacing. As water flows northeast from the Xul-Ha sinkhole into Laguna Bacalar, the water depth decreases, allowing for cyanobacteria to colonize the river bottom and begin the formation of microbialites. The microbialites are observed only in the southern part of the lake, decreasing in abundance to the north. They are completely absent at the town of Bacalar (some $14 \mathrm{~km}$ northeast of the Xul-Ha sinkhole). This suggests that $\mathrm{Ca}^{2+}$ and $\mathrm{HCO}_{3}{ }^{-}$ions are used in the formation of microbialites, and that as microbialites grow and utilize these ions, their concentration decreases to the point where calcium carbonate formation is no longer favorable. This model is supported by the observed northeastern depletion of $\mathrm{Ca}^{2+}$ and $\mathrm{HCO}_{3}{ }^{-}$in the lake water.

It is possible that similar changes during the Proterozoic would have caused a decrease in the calcification of microbialites, and decrease in their abundance and diversity. As to the cause of the possible changes to saturation state of the water, a decrease in $\mathrm{CO}_{2}$, a decrease in temperature, or the competition by other calcifying organisms would have directly impacted microbialite growth (Fischer 1965; Karhu and Epstein 1986; Kasting 1987; Riding and Liang 2005; Kasting and Howard 2006; Riding 2006b). A decrease in $\mathrm{CO}_{2}$ was the result of enhanced silicate weathering and the subsequent reduction in greenhouse gasses and temperature (Riding 1997, 2006), while calcium carbonate availability 


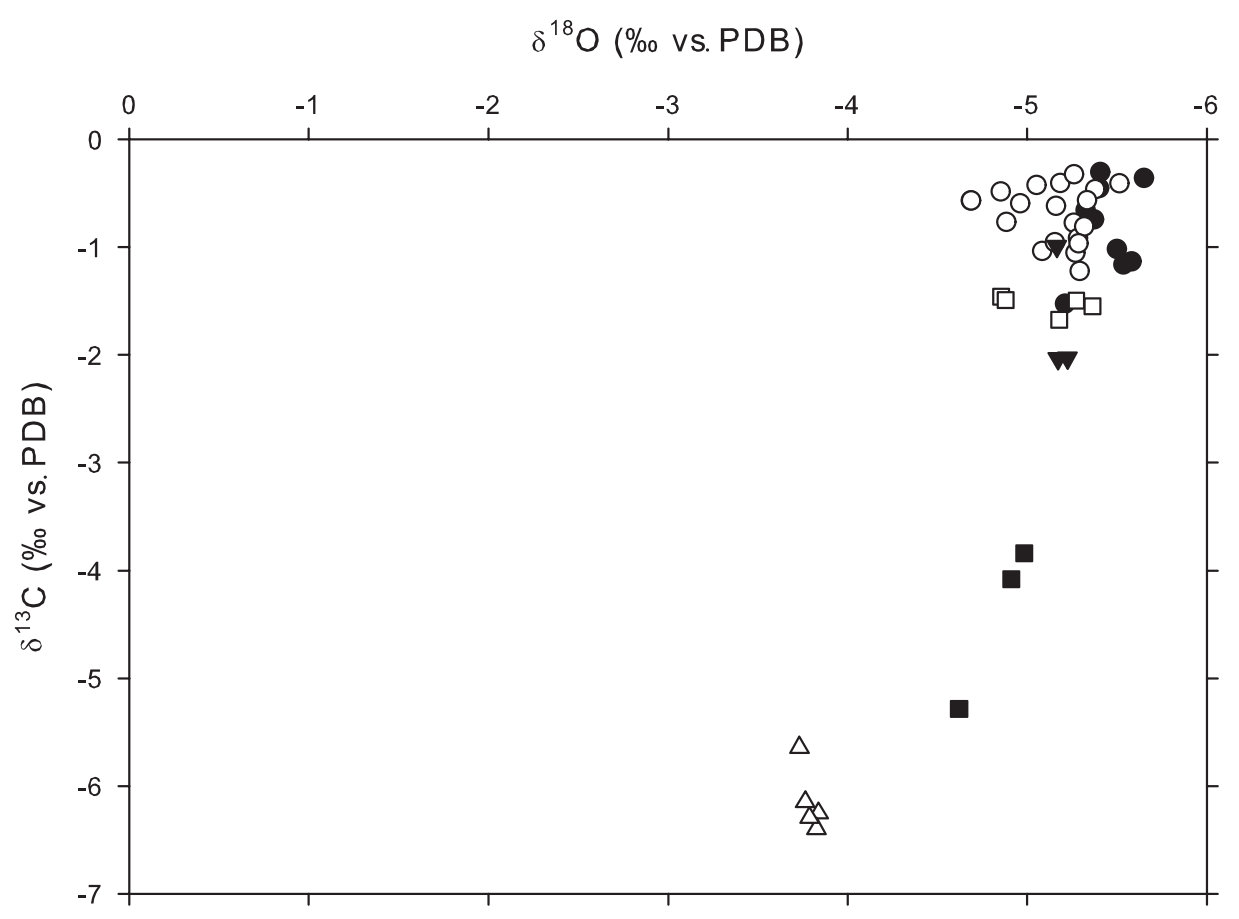

\begin{tabular}{|ll}
\hline & Thrombolitic-stromatolite Bac 1 \\
$\nabla$ & Thrombolitic-stromatolite Bac2 \\
$\Delta$ & Stromatolite \\
$\square$ & Brachiopods \\
$\square$ & Bivalves \\
\hline$\square$ & Sediment
\end{tabular}

would have been reduced due to the ability of animals to form carbonate exoskeletons (Fischer 1965).

Based on the discussion above, it also appears that the presence of bivalves and gastropods has no influence on microbialite growth. Bivalves only appear to use the microbialites as anchors, as is evident from their byssal threads (Fig. 7E) and the type of bivalve (Dreissena sp.), while showing no evidence of burrowing or grazing. The observed gastropods (Pomacea sp.), while having the ability to graze, showed no evidence of doing so, either due to the rapid growth or to the endolithic growth of the bacterial mat.

\section{CONCLUSIONS}

The growth and distribution of microbialites in Laguna Bacalar are controlled predominantly by the water carbonate chemistry. The supersaturation of the water with regard to calcium carbonate, and the photosynthetic activity of the cyanobacteria promote the precipitation of calcite, and the formation of large microbialites. However, the textural characteristics are the result of the different growth mechanisms that the benthic cyanobacterial communities employ. The presence of grazing gastropods (Dreissena sp.) appeared to have minimal, if any, influence on microbialite growth, likely due the fast growth rates and the unique protection that endolithic bacterial growth provides the cyanobacteria. Stromatolites are characterized by the precipitation of calcite, and formation of internal lamination, the result of rhythmic layering of lamina containing higher abundance of filaments, preceded by those
FIG. 12.-Oxygen versus carbon isotope measurements of thrombolitic stromatolites, stromatolites, lake sediment, bivalves, and gastropods. having higher porosity. In contrast, internal clotting is the result of bacterially induced trapping and binding of micritic peloids, which in combination with the laminated texture, form thrombolitic stromatolites. Isotopically microbialite carbonates are consistently enriched in $\mathrm{C}^{13}$ relative to bivalves and gastropods, while cyanobacterial photosynthetic $\mathrm{CO}_{2}$ uptake driving carbonate precipitation is the simplest explanation for such differences in the carbonate $\delta^{13} \mathrm{C}$ values. Geochemically, both microbialites are similar, having enrichment of biologically essential elements, most likely as a result of metal sorption to the EPS present. However, the concentrations in stromatolites are slightly higher, and attributed to the longer presence of cyanobacteria and its EPS. These findings suggest that Laguna Bacalar microbialites may be valuable modern-day analogues to their Neoproterozoic and Phanerozoic counterparts, and provide support for the hypothesis that water chemistry is the main determinant in promoting the growth of such large biogenic structures.

\section{SUPPLEMENTAL MATERIAL}

Data is available from the PALAIOS Data Archive: http://www.sepm. org/pages.aspx?pageid $=332$.

\section{ACKNOWLEDGMENTS}

The authors wish to thank Dr. Karlis Muehlenbachs who provided his valuable support in the acquisition of stable isotope data, Dee-Ann Rollings for her help with the SEM, GuangCheng Chen for his assistance with LA- 
ICPMS analyses, Sergei Matveev for his assistance with the microprobe analyses, and Mingsheng Ma for his assistance with anion analysis of the lake water. The careful and insightful reviews from both PALAIOS reviewers and associate editor J. Peckmann are greatly appreciated, as well that of fellow graduate student Aleksandra Mloszewska. Financial support for this project was provided by the Natural Sciences and Engineering Research Council to Canada (NSERC) to K.O.K and M.K.G.

\section{REFERENCES}

Aitken, J.D., 1967, Classification and environmental significance of cryptalgal limestones and dolomites with illustrations from the Cambrian and Ordovician of southwestern Alberta: Journal of Sedimentary Petrology, v. 37, p. 1163-1178

Allwood, A.C., Walter, M.R., Kamber, B.S., Marshall, C.P., and Burch, I.W., 2006, Stromatolite reef from the early Archaean era of Australia: Nature, v. 441, p. $714-718$.

Allwood, A.C., Grotzinger, J.P., Knoll, A.H., Burch, I.W., Anderson, M.S., Coleman, M.L., And KaniK, I., 2009, Controls on development and diversity of early Archean stromatolites: National Academy of Sciences, Proceedings, v. 106, p. 9548 9555

Andres, M.S., Sumner, D.Y., Reid, R.P., and Swart, P.K., 2006, Isotopic fingerprints of microbial respiration in aragonite from Bahamian stromatolites: Geology, v. 34 p. $973-976$.

Arp, G., Reimer, A., and Reitner, J., 2001, Photosynthesis-induced biofilm calcification and calcium concentrations in phanerozoic oceans: Science, v. 292, p. 1701-1704.

AwramiK, S.M., 1971, Precambrian columnar stromatolite diversity: reflection of metazoan appearance: Science, v. 174, p. 825-827.

Awramik, S.M., 1991, Archaean and Proterozoic stromatolites, in Riding, R., ed., Calcareous Algae and Stromatolites: New York, Springer-Verlag, p. 289-304.

Baptista, M.S., and Vasconcelos, M.T., 2006, Cyanobacteria metal interactions requirements, toxicity, and ecological implications: Critical Reviews in Microbiology, v. 32, p. $127-137$.

Bauer-Gottwein, P., Gondwe, B., Charvet, G., Marin, L., Rebolledo-Vieyra, M. And Merediz-Alonso, G., 2011, Review: the Yucatan Peninsula karst aquifer, Mexico: Hydrogeology Journal, v. 19, p. 507-524.

Bernhard, J.M., Edgcomb, V.P., Visscher, P.T., McIntyre-Wressnig, A., Summons, R.E., Bouxsein, M.L., Louis, L., AND JeglinsKI, M., 2013, Insights into foraminiferal influences on microfabrics of microbialites at Highborne Cay, Bahamas: Nationa Academy of Sciences, Proceedings, v. 110, p. 9830-9834.

BeuKes, N.J., 1987, Facies relations, depositional environments and diagenesis in a major early Proterozoic stromatolitic carbonate platform to basinal sequence, Campbellrand Subgroup, Transvaal Supergroup, Southern-Africa: Sedimentary Geology, v. 54, p. $1-46$.

Braissant, O., Cailleau, G., Dupraz, C., and Verrecchia, A.P., 2003, Bacterially induced mineralization of calcium carbonate in terrestrial environments: the role of exopolysaccharides and amino acids: Journal of Sedimentary Research, v. 73, p. $485-490$.

Buck, S.G., 1980, Stromatolite and ooid deposits within the fluvial and lacustrine sediments of the Precambrian Ventersdorp Supergroup of South-Africa: Precambrian Research, v. 12, p. 311-330.

Buczynski, C., AND Chafetz, H.S., 1991, Habit of bacterially induced precipitates of calcium-carbonate and the influence of medium viscosity on mineralogy: Journal of Sedimentary Petrology, v. 61, p. 226-233.

Buczynski, C., AND Chafetz, H.S., 1993, Habit of bacterially induced precipitates of calcium carbonate: examples from laboratory experiments and recent sediments, in Rezak, R., and Lavoie, D.L., eds., Carbonate Microfabrics: New York, SpringerVerlag, p. 105-116.

Burne, R.V., And Moore, L.S., 1987, Microbialites: organosedimentary deposits of benthic microbial communities: PALAIOS, v. 2, p. 241-254.

Chafetz, H.S., and Buczynski, C., 1992, Bacterially induced lithification of microbial mats: PALAIOS, v. 7, p. 277-293.

Conagua, 2002, Determinación de la disponibilidad de agua en el acuífero Peninsula de Yucatán, estado de Yucatán: Gerencia de Aguas Subterráneas, p. 1-20.

CRAIG, H., 1957, Isotopic standards for carbon and oxygen and correction factors for mass-spectrometric analysis of carbon dioxide: Geochimica Et Cosmochimica Acta, v. 12 , p. $133-149$

CraIG, H., 1961, Standard for reporting concentrations of deuterium and oxygen-18 in natural waters: Science, v. 133, p. 1833-1834.

DíAz, J.E.H., 2005, Decreto por el cual se establece el programa de ordenamineto ecologico territorial de al región de Laguna Bacalar, Quintana Roo, México: Periodico Oficial, $126 \mathrm{p}$.

Dupraz, C., Reid, R.P., Braissant, O., Decho, A.W., Norman, R.S., and Visscher, P.T., 2009, Processes of carbonate precipitation in modern microbial mats: EarthScience Reviews, v. 96, p. 141-162.

Fischer, A.G., 1965, Fossils early life and atmospheric history: National Academy of Sciences, Proceedings, v. 53, p. 1205-1213.

Gamboa-Perez, H.C., And Schmitter-Soto, J.J., 1999, Distribution of cichlid fishes in the littoral of Lake Bacalar, Yucatan Peninsula: Environmental Biology of Fishes, v. 54 , p. $35-43$.
Garrett, P., 1970, Phanerozoic stromatolites: noncompetitive ecologic restriction by grazing and burrowing animals: Science, v. 169, p. 171-173

Gischler, E., Gibson, M.A., and Oschmann, W., 2008, Giant Holocene freshwater microbialites, Laguna Bacalar, Quintana Roo, Mexico: Sedimentology, v. 55, p. 1293 1309

Gischler, E., Golubic, S., Gibson, M., Oschmann, W., and Hudson, J.H., 2011, Microbial mats and microbialites in the freshwater Laguna Bacalar, Yucatan Peninsula, Mexico, in Reitner, J., Trauth, M.H., Stüwe, K., and Yuen, D., eds. Advances in Stromatolite Geobiology: Berlin, Springer, p. 187-205.

Golubic, S., 1994, The continuing importance of cyanobacteria, in Bengtson, S., ed. Nobel Symposium; Early Life on Earth, p. 334-340.

Grotzinger, J.P., 1990, Geochemical model for Proterozoic stromatolite decline: American Journal of Science, v. 290A, p. 80-103.

Grotzinger, J.P., 1994, Trends in Precambrian carbonate sediments and their implication for understanding evolution, in Bengtson, S., ed., Early Life on Earth, Nobel Symposium 84: New York, Columbia University Press, p. 245-258.

Grotzinger, J.P., And Knoll, A.H., 1999, Stromatolites in Precambrian carbonates: evolutionary mileposts or environmental dipsticks?: Annual Review of Earth and Planetary Sciences, v. 27 , p. $313-358$

Hodell, D.A., Quinn, R.L., Brenner, M., and Kamenov, G., 2004, Spatial variation of strontium isotopes (Sr-87/Sr-86) in the Maya region: a tool for tracking ancient human migration: Journal of Archaeological Science, v. 31, p. 585-601.

Hofmann, H.J., 1973, Stromatolites: characteristics and utility: Earth-Science Reviews, v. 9 , p. $339-373$

Howard, A., 2012, Cyanobacteria (blue-green algae), in Bengtsson, L., Herschy, R., and Fairbridge, R., eds., Encyclopedia of Lakes and Reservoirs: Dordrecht, Netherlands, Springer, p. 174-175

JAROSEWICH, E., 2002, Smithsonian microbeam standards: Journal of Research of the National Institute of Standards and Technology, v. 107, p. 681-686.

Jones, B., Renaut, R.W., and Konhauser, K.O., 2005, Genesis of large siliceous stromatolites at Frying Pan Lake, Waimangu geothermal field, North Island, New Zealand: Sedimentology, v. 52, p. 1229-1252.

KaLKOWSKY, E., 1908, Oolith und stromatolith im norddeutschen Buntsandstein: Zeitschrift der deutschen geologischen Gesellschaft, v. 60, p. 68-125.

Karhu, J.A., And Epstein, S., 1986, The implication of the oxygen isotope records in coexisting cherts and phosphates: Geochimica Et Cosmochimica Acta, v. 24, p. 867 870 .

KASTING, J.F., 1987, Theoretical constraints on oxygen and carbon-dioxide concentrations in the Precambrian Atmosphere: Precambrian Research, v. 34, p. 205-229.

Kasting, J.F., And Howard, M.T., 2006, Atmospheric composition and climate on the early Earth: Royal Society of London, Philosophical Transactions, Biological Sciences, v. 361, p. 1733-1741.

Konhauser, K., 2007, Introduction to Geomicrobiology: Oxford, U.K., Blackwell Publishing, $425 \mathrm{p}$.

Konhauser, K.O., Jones, B., Phoenix, V., Ferris, G., and Renaut, R., 2004, The microbial role in hot spring silicification: Ambio, v. 33, p. 552-558.

López, Z.L., Lugo, F.A., AND PitA, M.R.S., 2005, Chetumal E16-4-7, Carta GeológicoMinera: Servicio Geológico Mexicano.

Lowe, D.R., 1983, Restricted shallow-water sedimentation of early Archean stromatolitic and evaporitic strata of the Strelley Pool Chert, Pilbara Block, Western Australia: Precambrian Research, v. 19, p. 239-283.

McConnaughey, T., Burdett, J., Whelan, J., and Paull, C., 1997, Carbon isotopes in biological carbonates: respiration and photosynthesis: Geochimica Et Cosmochimica Acta, v. 61, p. 611-622.

MCCreA, J., 1950, On the isotopic chemistry of carbonates and a paleotemperature scale: Journal of Chemical Physics, v. 18, p. 849-857.

McKee, E.D., Gutschick, R.C., And Skipp, B., 1969, History of the Redwall Limestone of northern Arizona: Geological Society of America, v. 4, p. 587-590.

McNamara, K.J., and Awramik, S.M., 1992, Stromatolites: a key to understanding the early evolution of life: Science Progress, v. 76, p. 345-364

Merz-Preifi, M., 2000, Calcification in cyanobacteria, in Riding, R., and Awramik, S.M., eds., Microbial Sediments: Berlin, Springer-Verlag, p. 50-56.

O'Leary, M.H., 1981, Carbon isotope fractionation in plants: Phytochemistry, v. 20 p. $553-567$

Park, R., And Epstern, S., 1961, Metabolic fractionation of $\mathrm{C}^{13}$ and $\mathrm{C}^{12}$ in plants: Plant Physiology, v. 36, p. 133-138.

Pentecost, A., 1978, Blue-green algae and freshwater carbonate deposits: Royal Society of London, Proceedings, Biological Sciences, v. 200, p. 43-61.

Pentecost, A., And Riding, R., 1986, Calcification in cyanobacteria, in Leadbeater, B.S.C., and Riding, R., eds., Biomineralization of Lower Plants and Animals: Oxford, U.K., Clarendon Press, p. 73-90.

Perez, L., Bugja, R., Lorenschat, J., Brenner, M., Curtis, J., Hoelzmann, P., Islebe, G., Scharf, B., And Schwalb, A., 2011, Aquatic ecosystems of the Yucatan Peninsula (Mexico), Belize, and Guatemala: Hydrobiologia, v. 661, p. 407-433.

Perri, E., ANd Spadafora, A., 2011, Evidence of microbial biomineralization in modern and ancient stromatolites, in Tewari, V.C., and Seckbach, J., ed., Stromatolites: Interaction of Microbes with Sediments: Dordrecht, The Netherlands, Springer, p. 633-649.

Perry, E., Velazquez-Oliman, G., and Marin, L., 2002, The hydrogeochemistry of the karst aquifer system of the northern Yucatan Peninsula, Mexico: International Geology Review, v. 44, p. 191-221. 
Perry, E., Paytan, A., Pedersen, B., and Velazquez-Oliman, G., 2009, Groundwater geochemistry of the Yucatan Peninsula, Mexico: constraints on stratigraphy and hydrogeology: Journal of Hydrology, v. 367, p. 27-40.

Petrash, D.A., Lalonde, S.V., Raudsepp, M., and Konhauser, K.O., 2011, Assessing the importance of organic matrix materials in biofilm chemical reactivity: insights from proton and cadmium adsorption onto the commercially available biopolymer alginate: Geomicrobiology Journal, v. 28, p. 266-273.

Petrash, D.A., Gingras, M.K., Lalonde, S.V., Orange, F., Pecoits, E., and Konhauser, K.O., 2012, Dynamic controls on accretion and lithification of modern gypsum-dominated thrombolites, Los Roques, Venezuela: Sedimentary Geology, v. $245-246$, p. $29-47$.

Planavsky, N.J., Reid, R.P., Lyons, T.W., Myshrall, K.L., and Visscher, P.T., 2009, Formation and diagenesis of modern marine calcified cyanobacteria: Geobiology, V. 7, p. 566-576.

Pratt, B.R., 1982, Stromatolite decline: a reconsideration: Geology, v. 10, p. 512-515.

Ridgwell, A., And Zeebe, R.E., 2005, The role of the global carbonate cycle in the regulation and evolution of the Earth system: Earth and Planetary Science Letters, V. 234 , p. 299-315.

RIDING, R., 1997, Stromatolite decline: a brief reassessment: Facies, v. 36, p. 227-230.

Riding, R., 1999, The term stromatolite: towards an essential definition: Lethaia, v. 32 , p. $321-330$.

RIDING, R., 2006a, Cyanobacterial calcification, carbon dioxide concentrating mechanisms, and Proterozoic-Cambrian changes in atmospheric composition: Geobiology, v. 4, p. 299-316.

RIDING, R., 2006b, Microbial carbonate abundance compared with fluctuations in metazoan diversity over geological time: Sedimentary Geology, v. 185, p. 229-238.

RIDING, R., 2011, The nature of stromatolites: 3,500 million years of history and a century of research, in Reitner, J., Quéric, N.-V., and Arp, G., eds., Advances in Stromatolite Geobiology: Heidelberg, Springer, p. 29-74.

Riding, R., AND Liang, L.Y., 2005, Geobiology of microbial carbonates: metazoan and seawater saturation state influences on secular trends during the Phanerozoic: Palaeogeography, Palaeoclimatology, Palaeoecology, v. 219, p. 101-115.

Schidlowski, M., 2000, Carbon isotopoes and microbial sediments, in Riding, R., and Awramik, S.M., eds., Microbial Sediments: Berlin, Springer-Verlag, p. 84-95.
SCHIEBER, J., 1999, Microbial mats in terrigenous clastics: the challenge of identification in the rock record: PALAIOS, v. 14, p. 3-12.

Schopf, J.W., 2006, Fossil evidence of Archaean life: Royal Society of London, Philosophical Transactions, Biological Sciences, v. 361, p. 869-885.

Schopf, J.W., Kudryavtsev, A.B., Czaja, A.D., And Tripathi, A.B., 2007, Evidence of archean life: stromatolites and microfossils: Precambrian Research, v. 158, p. 141 155.

ShapIRo, R.S., 2000, A comment on the systematic confusion of thrombolites: PALAIOS, v. 15 , p. 166-169.

Silva, J.J.R.F., AND Williams, R.J.P., 2001, The Biological Chemistry of the Elements: The Inorganic Chemistry of Life: Oxford, U.K., Oxford University Press, 575 p.

SiLver, S., 1998, Genes for all metals: a bacterial view of the periodic table: the 1996 Thom Award lecture: Journal of Industrial Microbiology and Biotechnology, v. 20, p. $1-12$.

Simkiss, K., and Wilbur, K.M., 1989, Biomineralization: Cell Biology and Mineral Deposition: San Diego, Academic Press, 337 p.

Servicio Meteorológico Nacional, 2000, Normales climatológicas de San Felipe Bacalar, Quintana Roo 1971-2000: Servicio Meteorológico Nacional de Mexico, p. 1-2.

Stal, L.J., 2000, Cyanobacterial mats and stromatolites, in Whitton, B.A., and Potts, M., eds., The Ecology of Cyanobacteria: Their Diversity in Time and Space: Dordrecht, Kluwer Academic Publisher, p. 61-120.

Visscher, P.T., Reid, R.P., Bebout, B.M., Hoeft, S.E., Macintyre, I.G., and Thompson, J.A., 1998, Formation of lithified micritic laminae in modern marine stromatolites (Bahamas): the role of sulfur cycling: American Mineralogist, v. 83, p. $1482-1493$.

Walter, M.R., and Heys, G.R., 1985, Links between the rise of the metazoa and the decline of stromatolites: Precambrian Research, v. 29, p. 149-174.

Wood, R.A., Grotzinger, J.P., And Dickson, J.A.D., 2002, Proterozoic modular biomineralized metazoan from the Nama Group, Namibia: Science, v. 296, p. 2383 2386

Received 25 June 2013; accepted 27 February 2014. 